\title{
Editorial Report 2013
}

\author{
Jan van Ours
}

Published online: 26 February 2014

(C) Springer Science+Business Media New York 2014

The 4 issues of De Economist published in 2013 contain 20 papers of which 14 papers were published in regular issues and 6 papers were published in a special issue on retirement and employment opportunities for older workers. The special issue with guest editor Pierre Koning contains papers on individual retirement expectations, retirement incentives in Belgium, French retirement reforms, downsizing during the Great Recession, re-employment rates of older unemployed workers and subjective well-being around retirement. The regular issues cover a wide range of topics with for example papers on economic development in the Netherlands from 1510 to 1900, private saving imbalances, pension system design in the EU, school dropouts and cultural and artistic education in the Netherlands. The impact factor of De Economist increased from 0.26 in 2008 to 0.77 in 2011 . The 2012 impact factor was 0.80 .

The table below provides additional information. In 2013 there were 50 regular submissions, somewhat more than in 2012. As shown in the table below, of these 50 submissions so far 4 were accepted, 35 were rejected, and 11 are still in the editorial process. Of the rejected papers 25 were desk-rejections, i.e. rejected within a week after submission. Excluding the papers which were desk-rejected there is a small decline compared to 2012 when there were 29 regular submissions. In 2013 this was 25. Of the papers excluding desk rejections the acceptance rate in 2012 was $34 \%$. In 2013 this was $16 \%$, but there are still 11 papers in the editorial process so the 2013 acceptance rate will go up in the course of 2014. The table also shows that the average duration until first decision-revise \& resubmit or rejection-went down from 81 days in 2012 to 63 days in 2013. Finally, the table shows the relationship between year of submission and year of publication. For example, of the 14 papers submitted and

\footnotetext{
J. van Ours $(\varangle)$

Tilburg, The Netherlands

e-mail: deeconomist@gmail.com
} 


\begin{tabular}{llll}
\hline Number of papers submitted in & 2013 & 2012 & 2011 \\
\hline Accepted & 4 & 10 & 8 \\
Regular rejection & 10 & 19 & 18 \\
Desk rejection & 25 & 15 & 17 \\
Stock December 31, 2012 & 11 & 0 & 0 \\
\hline Sub-total & 50 & 44 & 43 \\
Special issues + editors contributions & 10 & 4 & 9 \\
\hline Total & 60 & 48 & 52 \\
Regular papers excl. desk rejections & & & 26 \\
Number & 25 & 29 & 31 \\
Acceptance rates (\%) & 16 & 34 & 108 \\
Days to first decision & 63 & 14 & 17 \\
Accepted papers & 14 & & - \\
Published in & & 1 & 1 \\
2014 & 3 & 8 & 14 \\
2013 & 11 & 5 & 2 \\
2012 & - & - & \\
2011 & - & &
\end{tabular}

accepted for publication in 2013, 11 were published in 2013 while the remaining 3 will be published in 2014 .

Since 2011 the editors allow authors to include in the submission editorial letters and referee reports from failed submissions at other journals. This does not mean that no other referees will be used, but the use of previous information will speed of our editorial process. So far, not many authors have used this possibility.

The editors of De Economist would like to thank the following reviewers for their contribution to the editorial process:

$\begin{array}{ll}\text { Jaap Abbring } & \text { Arjan Lejour } \\ \text { Michele Belloni } & \text { Aljar Meesters } \\ \text { Jaap Bos } & \text { Geert Mesters } \\ \text { Maarten Bosker } & \text { Raymond Montizaan } \\ \text { Harry van Dalen } & \text { Matteo Picchio } \\ \text { Thomas Dohmen } & \text { Eduard Ponds } \\ \text { Nick Draper } & \text { Felix Rioja } \\ \text { Adam Elbourne } & \text { Hugo Rojas-Romagosa } \\ \text { Rob Euwals } & \text { Marc Schramm } \\ \text { Hans Fehr } & \text { Arthur van Soest } \\ \text { Didier Fouarge } & \text { Adriaan Soetevent } \\ \text { Franc Klaassen } & \text { Laura Spierdijk } \\ \text { Tobias Klein } & \text { Daniel van Vuuren } \\ \text { Pierre Koning } & \text { Jan van Ours } \\ \text { Peter Kooreman } & \text { Managing editor } \\ \text { Erno Kuiper } & \end{array}$

